\title{
Where Does Diversity Go Straight? Biopolitics, Queer of Color Critique, and Music Education
}

\author{
Elizabeth Gould
}

\begin{abstract}
Diversity discourses in music education have evolved from (white) liberalism of the 1990s that conceived difference in terms of dualisms such as insider/ outsider to global neoliberalism currently in which sources of difference are interchangeable as long as the historicity of each remains occluded. In this way, so-called "diversity-relevant" groups, such as white queer people are positioned against non-white groups, straight or otherwise, in ways that support neoliberalism and contribute to violence against the latter. To ask where diversity goes straight assumes a place where it is not straight - if not exactly queer, with queer understood (in the context of race) as a "refusal to inherit" kinship relations in which queer(s) disappear (s). Whether conceived in terms of culture, race, (dis)ability, gender, and/or sexuality, diversity has become "all the rage" in music education and academic research generally. Theorizing diversity discourses in music education at their discursive limits, I argue that those limits are also where they also may be exceeded and demonstrate this through an example using queer of color critique to analyze interactions of sources of difference as a way to historicize and racialize "diversity" in music education.
\end{abstract}

Keywords Diversity $\cdot$ Queer $\cdot$ Biopolitics $\cdot$ Race $\cdot$ Music education

\section{Introduction}

To ask where diversity goes straight assumes a place where diversity is not straight - if not exactly queer, with queer understood (in the context of race) as a "refusal to inherit" kinship relations in which queer(s) disappear(s) (Ahmed 2006). Whether conceived in terms of culture, race, (dis)ability, gender, and/or sexuality, diversity has become "all the rage" in music education and academic research

\footnotetext{
E. Gould $(\bowtie)$

Faculty of Music, University of Toronto, Toronto, ON, Canada

e-mail: e.gould@utoronto.ca
} 
generally. Our metaphorical and material trafficking in diversity may be described as cool (Horning 2013): "a new fusion of social and cultural capital with demonstrable competencies in consumption-knowing what to buy [research and travel], and when, and how to seize opportunities to display [present and publish] it" (para7). As the very definition of cool, queer theory also is a "hot commodity," evidenced by changes in the politics of diversity from music education's liberalism of the 1990s based on difference expressed through dualisms (rather than "binaries") ${ }^{1}$ such as insider/outsider, to the biopolitics of global neoliberalism now.

In this chapter I take up neoliberalism using the vocabulary of French philosopher and social theorist, Michel Foucault, as a "power-knowledge regime ... shap[ing] subjectivity, relations of production, gender and race politics, ... artistic practices and aesthetics" (James 2014b, p. 139) and theorize "diversity" at its discursive limits through Judith Butler's (1993) discussion of the discursive limits of "sex." With diversity "the explicit aim of neoliberalism" (Winnubst 2012, p. 94), I argue that cultural diversity discourses in music education implicating music (James 2014b) and race support and maintain the biopolitics of neoliberalism in which all diversityrelevant (Dobusch 2017) groups are interchangeable, positioning cool, straight (ened) white queer gender/sexuality groups against non-white, obliquely positioned groups in ways that uphold neoliberalism, contributing to state violence and antidemocratic ends (Ludwig 2016). Biopolitical neoliberalism may be where cultural diversity discourses in music education confront their discursive limits, but it is also where they may exceed them with queer of color critique, which emerged from women of color feminism and Black ${ }^{2}$ lesbian feminism during the 1970s and1980s as "a reading practice" examining interactions of race, gender, sexuality, and class, in and as "histories of racialization" (Ferguson and Hong 2012) and sexualization. Queer of color critique provides the frame for my analysis historicizing and racializing "diversity" in music education.

\section{On the Discursive Limits of "Diversity"}

Butler (1993) argues that "sex" is normative; in Foucauldian terms, it is a "regulatory ideal":

In this sense, then, "sex" not only functions as a norm, but is part of a regulatory practice that produces the bodies it governs, ... whose regulatory force is made clear as a kind of productive power, the power to produce - demarcate, circulate, differentiate-the bodies it controls. Thus, "sex" is a regulatory ideal whose materialization is compelled, and this materialization takes place (or fails to take place) through certain highly regulated practices. In other words, "sex" is an ideal construct which is forcibly materialized through time. (p. 2)

\footnotetext{
${ }^{1}$ Binaries are parallel or opposing terms; neither is intrinsically more valued than the other. Dualisms are closed hierarchical systems that value the first term over the second.

${ }^{2}$ I use "Black" in reference to African Americans living in the USA but also to resist biopolitical diversity in which any "diverse" (in this context, non-white) group may be exchanged for any other. I use "white" as an adjective; it does not refer to any specific national, cultural, or ethnic group.
} 
Rethinking materiality as "the effect of power" (p. 3), Butler insists that subjects do not possess or are defined by "sex"; rather "sex" is "one of the norms by which [a subject] becomes viable[,] ... that which qualifies a body for life within the domain of cultural intelligibility" (p. 2). She refutes "second wave" feminist concepts of "gender" as the social construction of biological "sex," arguing that (social/ cultural) constructions of "sex" as "gender" assume "the cancellation of the natural [sex] by the social [gender]" (p. 5), and ignore the historicity of "sex." Moreover, concepts of gender construction presume a subject that precedes or follows its construction-rather than the performative "I" produced discursively as an ontological effect (condition of human existence) through "a process of materialization that stabilizes over time to produce the effect of boundary, fixity, and surface we call matter" (p. 9, emphasis original). In other words, the material(ized) gendered body is not indicative of an inner essence that an already gendered subject performs and society reads but is produced (materializes) as a function of repeated iterations (presentations) of gender "through the gesture, the move, the gait (that array of corporeal theatrics understood as gender presentation)" (Butler 1991, p. 28). A central question related to bodies produced as an effect of discourse addresses how bodies that do not materialize support and "provide the necessary 'outside' ... for the bodies which, in materializing the norm, qualify as bodies that matter" (p. 16) in this discussion, bodies that are diversity-relevant.

Conceiving regulatory ideals as "always a racial industry, ... the reiterated practice of racializing interpellations" (p. 18, emphasis original), Butler concurs with theories that argue that "'race' is partially produced as an effect of the history of racism and that its boundaries and meanings are constructed over time, not only in the service of racism but also in the service of the contestation of racism" (p. 18). Further, she rejects that race, gender, sexuality, and by implication other ontological differences are equivalent, parallel, or analogous; rather, they are "the conditions of articulation for each other" (p. 117, emphasis original), which is to say, gender, sexuality, and race not only intersect with each other but interact, as well.

\section{Neoliberalism, Biopower, Biopolitics}

Roderick Ferguson (2004) argues that neoliberalism "denotes the triumph of liberal ideology through racial and class exclusion and through the expansion of normative gender and sexual regimes" (p. 115) in a "contradictory occurrence" by which liberatory movements enact exclusions. For example, US and European feminism formulated in the nineteenth and twentieth centuries enacted exclusions based on race and queer sexuality, while Black nationalist movements in the USA during the middle/late twentieth century enacted exclusions based on gender and queer sexuality. These racial and gender exclusions are articulated in the title of the feminist women of color anthology, All the Women are White, All the Blacks are Men, but Some of Us are Brave (Hull et al. 1982). Racial, gender, and queer sexuality exclusions facilitate the universalization of white heteropatriarchy- "any system 
of social organization that assumes white hetero-masculinity as a norm, and compels us to distribute privilege and oppression according to this norm" (James 2013, p. 103) - in neoliberalism, producing heteronormativity as a white social formation, with all non-white sexuality, including non-white heterosexuality, produced as non-heteronormativity (Ferguson 2004).

Foucault (2003) traces biopower to the late eighteenth and early nineteenth centuries during the rise of industrialization, describing it as "a new technology of power" (p. 243). Activated through biopolitics- "a power addressed to life" (James 2014b, p. 140; emphasis original)—in neoliberal societies, biopower is implicated in state racism associated with colonization and war (Foucault 2003), as well as in sexism and homophobia produced through medicalized discourses of the late nineteenth century. Instead of replacing disciplinary power, however, biopower complements it. The former disciplines individual bodies in terms of a sovereign's power to adjudicate death: "to take life or let live," while the latter administers populations in terms of life, "the power to foster life or disallow it to the point of death" (Foucault 1978/1990, p. 138, emphasis original). Similarly, disciplinary power disciplines individuals through institutions of surveillance and training (schools, hospitals, prisons), while biopower administers groups through "complex systems of coordination and centralization guarantee[ing] the optimal longevity of the population" (Foucault 2003, pp. 250, 251). Succinctly, "biopolitical neoliberalism ... uses statistics to optimize the life of some (privileged) groups, intensifying their access to 'life' by deintensifying the access of others" (James 2012, para. 8). Sexuality, because it "exists at the point where body [disciplinary power] and the population [biopower] meet" (Foucault 2003, pp. 251-252), becomes enormously important in biopolitics, requiring individualized disciplinary controls of behavior as well as generalized administration related to procreation and sexual health of the population. This also makes sexuality particularly vulnerable to neoliberal incorporation and monetization (Ferguson and Hong 2012).

Because neoliberalism attempts "to transform society itself into a mode of enterprise, ... of creative and competitive subjects" (Winnubst 2012, p. 83), difference is flattened and divested of historicity. Infinitely fungible, one form of difference such as race may be replaced by another, such as gender/sexuality, demonstrating how select groups become diversity-relevant at the expense of others. More perniciously, "the flexibilization of the apparatus of sexuality is ... deployed to legitimate ... antidemocratic and violent neoliberal state[s]" (Ludwig 2016, p. 417). Extending this "violent dynamic of biopower" (p. 425) whereby some groups are "killed" so that others may live is the point where "racism intervenes" (Foucault 2003). "[I]nscribed as the basic mechanism of power ... exercised in modern States" (p. 254), "racism ... makes killing acceptable" (p. 256). Beyond actual murder, "killing" includes "every form of indirect murder: ... exposing someone to death, increasing the risk of death for some people, ... political death, expulsion, rejection" (p. 256). Biopower transforms a relationship of war (kill or be killed) into a "biological relationship" to protect the population.

Celebrating and legalizing white monogamous homosexuality, "homo-tolerant" neoliberal states in Europe and North America privatize social issues like sexuality in order to depoliticize them, creating conditions where individuals (discourses) 
marketize themselves, acting on their own behalf rather than for the collective public good. In music education and academic music programs generally, belated homotolerance is expressed in terms of a depoliticized form of social justice based on inclusion. With diversity monetized, difference is "intensified, multiplied and fractured" (Winnubst 2012, p. 93) in neoliberal biopolitics based less on capital than the human capital of individuals capitalizing themselves in ways that support hegemonic institutions, including hegemonic diversity discourses in music education. Rather than diversity conceived in terms of identity and transgressive difference associated with liberal ideology upholding white heteropatriarchy in (1990s) diversity discourses in music education, the biopolitics of "neoliberalism operates through the social rationality of success" (p. 96) in which everyone, at least in Western societies, is implicated regardless of their politics or ideological allegiances.

\section{Historicizing/Racializing Gender/Sexuality Diversity in Music Education}

During the late twentieth century, gays and lesbians in North America and Europe sought access to heteropatriarchal institutions such as marriage and the military (and music education in the USA early in the twenty-first century) by asserting homosexuality as "a new category of normativity" (Ferguson 2005, p. 56), socially constructing it as "ethnically" white, a more neutral and geographically locatable term that is often used instead of race in European neoliberal discourse (El-Tayeb 2011). Lisa Duggan (2003) characterizes this as homonormativity by which society (music education) accepts (white/monogamous) homosexuals who uphold, rather than challenge, the ideals of heterosexuality, rendering them diversity-relevant (cool) to the extent they are like heterosexuals. In this way, sameness (resemblance) becomes a prerequisite of equality (Richardson 2005). Neither queer teachers and queer students, nor their experiences in US high schools, can be construed as the same as heterosexual teachers and students-even in music classrooms (Bergonzi 2009). Further, verbal harassment that queer students are virtually guaranteed to experience in high school extends into adulthood, particularly for non-white transgender people (Emlet 2016; Langenderfer-Magruder et al. 2016; Powell 2018).

Noting that the "interaction of race, class, and gender in constructions of deviant sexualities creates more complicated groupings and hierarchies," Fatima El-Tayeb (2011) posits "queer ... in opposition to homonormative formations," arguing that "Europeans of color are produced as 'queer,' 'impossible' subjects in heteronormative discourses of nation as well as migration" (p. xxxv, emphasis original). Although physically imposing, gay African American marching band drum major Robert Champion, Jr., was so impossible that the band's percussionists beat him to death, after which officials at Florida A\&M University, the historically Black university they all attended, blamed Champion for participating in the brutal hazing ritual (Montgomery 2012; The NBJC Blog 2012). Jasbir Puar (2007) 
addresses issues of queerness and nationalization by combining Duggan's neologism with nationalism, as a contraction of "homonormative nationalism" or "national homosexuality," creating homonationalism, which Puar contends, detaches white "U.S. national gays and queers from racial and sexual others" (p. 39), specifically terrorists and migrants. Homonormativity and homonationalism depend on active complicity of gender/sexually diverse people, who underscore their similarity to normative (white) heterosexuals in the first instance and their dissimilarity to nonnormative (non-white) immigrants, refugees, and terrorists in the second.

Biopolitics intensifies this formulation by carrying "the economic calculation of enterprising, entrepreneurial interests into all domains of social, political, personal and even ethical life," making Duggan's homonormativity "a problem of "homoneoliberalism"” (Winnubst 2012, p. 94)—in music education cultural diversity discourses. Neoliberalism's "fungible machine of enterprise" depends on obscuring historical differentiations of all categories of difference, not only gender/sexuality, race and class but those based on (dis)ability, negating "heterogeneity among communities' and people's subject positions, resources, ways of living, and desires" (Ludwig 2016, p. 422). Dehistoricized and decontextualized, with no connection or reference to the violence incited by, in this case, homo-, bi-, and transphobia, queer people are "straight" (liberal ideology), "cool" (biopolitical neoliberalism)—and worthy of celebration (music education cultural diversity discourses).

\section{Diversity Discourses in Music Education}

Discourses of "diversity" in music education are reflexively associated with culture, expressed axiomatically as cultural diversity in music education. With neoliberalism, culture like virtually everything, is "used as a tool of capitalism," not only in an effort to make difference fungible and "empty out a politics of difference" (ChanTibergien 2006, p. 91, 102) but also to further the goals of the state and its hegemonic institutions, such as (typically) public school-based music education. Whether conceived in terms of educational projects requiring and producing curricular and pedagogical goals, outcomes and materials, professional development activities, such as in-service workshops, recurring conferences located around the world as a form of intellectual tourism, and various types of publications, performances, and recordings, cultural diversity in music education monetizes the human capital of all those involved in it.

The means by which nonnormative gender/sexuality functions in music education diversity discourses is not straightforward, however. It does not actualize in a hegemonic profession founded and funded, in neoliberal terms on white heteropatriarchy - even though that profession in Europe and North America is populated by gender/sexual others it historically sought to exclude: non-white people, women, and nonnormative gender/sexually diverse people. Neoliberal biopolitics turns this equation on its head for all diversity-relevant groups, as long as their historicity remains occluded and as a group they conform to white 
heteropatriarchal ideals, making them a good investment in that they produce "profitable human capital ... whose surplus value supports hegemonic institutions" (James 2014b, p. 149) such as cool cultural diversity discourses in music education predicated on inclusion (Gould 2013).

Music associated with people who are gender/sexuality nonnormative is extravagantly heterogeneous (Taylor 2012a), not only because queer people are diffused into every culture, society, and school but also due to their general invisibility in those cultures, societies, and schools - where they constitute neither an identifiably coherent culture as traditionally conceived nor a subculture situated in relationship to a dominant gender/sexuality culture (Taylor 2012b; Halberstam 2005). The heterogeneity of gender(s)/sexualit(ies)y militates against the former, while the latter is complicated by assimilationist impulses of dominant gender/sexuality that occur even as deviant gender(s)/sexualit(ies)y fracture among and between themselves musically and politically-underscoring, as well, how/why concepts of "cultural competence" and/or authenticity are inapplicable to queer diversity in music education. Without "institutions for common memory and generational transmission" (Warner 1999, p. 51), such as schools and the nuclear family, queer youths have only a vague sense of queer history, as an effect of the politics of shame ${ }^{3}$ by which queer people are stigmatized socially and legally, attacked, and murdered literally (Cover 2013; Gruenewald and Kelley 2014; Mayers 2018). More prosaically, the politics of shame routinely involves "silent inequalities, unintended effects of isolation, and ... lack of public access" (Warner 1999, p. 7).

Shamed and isolated, queer youths (and adults) listen to music that resonates with them, which "strikes a chord" (Wasserbauer 2016), cobbling together a bricolage of musical styles and artists (Taylor 2012a) to whom they are exceptionally emotionally attached (Dolan 2012; Wasserbauer 2016). So-called queerness in music historically has been associated (in the USA and Canada) with activities and sensibilities consistent with white, urban, affluent gay male culture, such as drag and camp (Jarman-Ivens 2016; Taylor 2013), as well as with stereotypes of music genres. For example, opera, Broadway musicals (Koestenbaum 1993), and disco signify gay (Dyer 2002), while symphonies, (absolute) instrumental music (Ives 1991), and rock signify straight (Greene 2014). The disco-rock/gay-straight juxtaposition was vividly demonstrated in 1979 when thousands of straight-presenting white young men chanted "Disco sucks!" as over 50,000 disco records were literally blown up in Comiskey Park (home of the Chicago White Sox baseball team) during what was called "Disco Demolition Night," the apex of a nationwide "antidisco backlash" directed against the music genre and people associated with "disco culture" constructed as "gay and elitist" (Frank 2007, p. 278). By contrast, music (mostly folk but also rock and jazz) composed and performed by mostly white lesbian musicians in the 1970s enjoyed an intense and enthusiastic (white) lesbian audience, even as it generated so little attention from the straight white press and music industry that it was utterly obscure to the general public (Gould 2016).

\footnotetext{
${ }^{3}$ Hence queer celebrations focus on pride—rather than power.
} 
The importance of affect for queer listeners, young and older, is primary and ubiquitous, suggesting that the "rubric of "queer music" may be productively understood in terms of an "ambiguous set of ideologies" that hinge as much on the creator's "intention and self-styled presentation as they are performatively located in the way the music is read and rearticulated" by listeners (Taylor 2012a, p. 150). This includes multiple musical styles: "rock, punk, metal, hip-hop, electronic dance music (EDM) and pop" (Taylor 2013, p. 194). Scholars in music, sociology, and music education regularly associate music with identity formation (e.g., Bowman 2004; Cook 1998; DeNora 2003; Lum 2017), but this process is rather more fraught for queer youth who do not readily find music groups and musicians with whom to identify-including in music education classrooms focused on issues of diversity. Cultural diversity research in music education may resist "privileges of heterosexuality" (Bergonzi 2009, p. 22) by using queer of color critique to analyze spaces that canonic music education research overlooks, despite their importance in the lives of queer students, families, schools, and communities. Natasha Sandraya Wilson's (2009) research of a queer space in New Orleans, the city which likely had "the largest black/African American queer population" (p. 119) in the USA before the devastating impact of Hurricane Katrina and its aftermath in 2005, demonstrates how queer of color critique might be taken up in cultural diversity research in music education.

\section{Potentialities of Queer of Color Critique in Music Education}

In a small nightclub known as the Groove, located in the impoverished, African American 7th Ward of New Orleans "female bodied women (FBWs), female bodied men (FBMs), and male bodied women (MBWs)" (Wilson 2009, p. 105), sing what they call the "lesbian anthem," despite describing themselves as "gay" or in "the gay life" rather than "lesbian"; and the song they sing along to, rhythm and blues singer Miliria's recording of "Three's a Crowd," is about (heterosexual) infidelity rather than same-sex desire between women. With its capacity to "invoke a shared vision, history, experience, or consciousness" (p. 105), the song functions as an anthem for this community of poor, African American drag queens and gay African American women, the vast majority of whom have children whose fathers are caught up in the US “prison industrial complex" (Davis 2002):

The music begins, and before [the performer] walks out onto the stage, the melody hits the crowd and almost immediately, everyone starts to say, "Awh, yeah!" Some people raise their drinks in the air and lower their heads, a gesture that indicates something that has personal resonance. Arms fly into the air with palms facing up and fingers spread apart. Some fingers begin to snap while arms are still up in the air and everyone's body is moving back and forth with the rhythm of the song. (Wilson 2009, p. 104, emphasis added) 
In addition to race, gender, and sexuality, Wilson addresses in her analysis how poverty and so-called welfare reform in the USA impact the lives of African American same-sex couples who present as women. She notes that the rich musical history of New Orleans provided a ground from which their cultural performance emanated - with rhythm and blues rather than jazz, which has attained the status of "“high' art in New Orleans," making it inaccessible to impoverished African Americans. Invoking queer of color critique, Wilson continues:

\footnotetext{
These rituals and cultural performances are necessarily connected to the various injustices that plague these women's lives and the lives of women in general. They are also about more than "queer" subjectivity, but they demand that we ask penetrating questions. Why are male bodied men-children's fathers - caught in the revolving door of the prison industrial complex? Why are female bodied women trapped in various relationships where they are mistreated? Why do female bodied men live with the fear of sexual assault? Why are there members of this community who cannot read and write? To answer any of these questions requires an honest interrogation of the institutions of the political economy in which the Groove and its communities [and schools] are embedded and the pervasive inequalities central to US society. (p. 119, emphasis added)
}

Taking up these questions in queer spaces with music and people who are neither diversity-relevant nor cool, cultural diversity discourses in music education might defund neoliberalism and "go into the death" (James 2015) of biopolitical fungibility, materializing - not celebrating-diversity, rendering it uncool by investing in people, students, and musics who do not currently exist in hegemonic cultural diversity in music education curricula and research, those groups and individuals (students) neoliberalism produces as excess, leaving them to biopolitical death.

Robin James (2015) describes this tactic of "counter-resilience" as melancholy: "the refusal to do the affective cultural labor [heteropatriarchal] capitalism requires of potentially resilient people [and potentially resilient cultural diversity discourses in music education]" (p. 141, emphasis original). Resilience discourses make us responsible for overcoming damage inflicted by white heteropatriarchy (James 2014a). Instead of demonstrating resilience by including what has been historically excluded, "queered" cultural diversity in music education intensifies exclusions as melancholy, injecting them into the profession/pedagogy/curriculum as "bad vibes," which is to say, "failed" or "misfired resilience" that produces "antisocial effects" unsettling and "killjoying" the white heteropatriarchal project of canonic music education through distinctly counterproductive means.

The political death of others cannot be resisted or foreclosed by cultural diversity in music education discourses of inclusion - which infer hierarchy and positionality, discursively producing a "domain of abjection" (Butler 1993, p. 3), as a constitutive outside, "a domain of unlivability and unintelligibility" (p. 22). Taking up queer of color critique as "a living methodology" (Chan-Tibergien 2006, p. 102) to reframe and rewrite the biopolitics of diversity through "a multiplicity of narrative knowledges in overlapping [sexual, gender, racial, economic] communities" (p. 99), cultural diversity in music education research might "realize a new democracy" (p. 100) grounded in the lived experiences of uncool diverse populations of students, musics, and communities. This necessitates changing what we do as well as what we think 
we know about ourselves, our profession, its purposes, and complicity in white heteropatriarchy and take up Wilson's question: Where/who are the displaced/ discounted/disallowed/discordant musics/peoples/communities in cultural diversity in music education?

\section{References}

Ahmed, S. (2006). Queer phenomenology: Orientations, objects, others. DurhamlLondon: Duke University Press.

Bergonzi, L. (2009). Sexual orientation and music education: Continuing a tradition. Music Educator's Journal, 100(4), 21-25.

Bowman, W. (2004). The song is you: Symposium on musical identity. Action, Criticism, Theory for Music Education, 3(1). http://act.maydaygroup.org/articles/Bowman3_1.pdf.

Butler, J. (1991). Imitation and gender insubordination. In D. Fuss (Ed.), Inside/out: Lesbian theories, gay theories (pp. 13-31). New YorklLondon: Routledge.

Butler, J. (1993). Bodies that matter: On the discursive limits of "sex". New YorklLondon: Routledge.

Chan-Tibergien, J. (2006). Cultural diversity as resistance to neoliberal globalization: The emergence of a global movement and convention. Review of Education, 52, 89-102.

Cook, N. (1998). Music: A very short introduction. Oxford: Oxford University Press.

Cover, R. (2013). Conditions of living: Queer youth suicide, homonormative tolerance, and relative misery. Journal of LGBT Youth, 10(4), 328-350.

Davis, A. Y. (2002). Policing the national body: Sex, race, and criminalization. Cambridge, MA: South End Press.

DeNora, T. (2003). Music sociology: Getting the music into the action. British Journal of Music Education, 20(2), 165-177. https://doi.org/10.1017/s0265051703005369.

Dobusch, L. (2017). Diversity discourses and the articulation of discrimination: The case of public organisations. Journal of Ethnic and Migration Studies, 43, 1644-1661. https://doi.org/10. 1080/1369183X.2017.1293590.

Dolan, J. (2012). Feeling women's culture: Women's music, feminism, and the impact of emotional memory. Journal of Dramatic Theory and Criticism, 26(2), 205-219.

Duggan, L. (2003). The twilight of equality? Neoliberalism, cultural politics, and the attack on democracy. Boston: Beacon Press.

Dyer, R. (2002). In defense of disco. In Only entertainment (2nd ed., pp. 151-159). New York: Routledge.

El-Tayeb, F. (2011). European others: Queering ethnicity in postnational Europe. Minneapolis London: University of Minnesota Press.

Emlet, C. A. (2016). Social, economic, and health disparities among LGBT older adults. Generations, 40(2), 16-22. https://www.ncbi.nlm.nih.gov/pmc/articles/PMC5373809/.

Ferguson, R. A. (2004). Aberrations in black: Toward a queer of color critique. Minneapolis: University of Minnesota Press.

Ferguson, R. A. (2005). Race-ing homonormativity: Citizenship, sociology, and gay identity. In E. P. Johnson \& M. G. Henderson (Eds.), Black queer studies: A critical anthology (pp. 50-57). DurhamLLondon: Duke University Press.

Ferguson, R. A., \& Hong, G. K. (2012). Reflections: The sexual and racial contradictions of neoliberalism. Journal of Homosexuality, 59, 1057-2012.

Foucault, M. (1990). The history of sexuality, volume 1: An introduction (R. Hurley, Trans.). New York: Vintage Books. French edition: Foucault, M. (1978). La volonté de savoir. Paris: Éditions Gallimard. 
Foucault, M. (2003). "Society must be defended" Lectures at the Collège de France, 1975-76 (D. Macey, Trans.). New York: Picador. French edition: Foucault, M. (1997). Il faut défendre la société. Paris: Éditions de Seuil/Gallimard.

Frank, G. (2007). Discophobia: Antigay prejudice and the 1979 backlash against disco. Journal of the History of Sexuality, 16(2), 276-306.

Gould, E. (2013). Companion-able species: A queer pedagogy for music education. Bulletin of the Council for Research in Music Education, 197, 63-75.

Gould, E. (2016). Ecstatic abundance: Queer temporalities in LGBTQ studies and music education. Bulletin of the Council for Research in Music Education, Winter/Spring, 207-208, 123-138.

Greene, D. (2014). The rock cover song: Culture, history, politics. Jefferson: McFarland and Company.

Gruenewald, J., \& Kelley, K. (2014). Exploring anti-LGBT homicide by mode of victim selection. Criminal Justice and Behavior, 41(9), 1130-1152.

Halberstam, J. (2005). In a queer time and place: Transgender bodies, subcultural lives. New York London: New York University Press.

Horning, R. (2013). The primitive accumulation of cool. The New Inquiry, 10(June). https:// thenewinquiry.com/blog/the-primitive-accumulation-of-cool/

Hull, G. T., Scott, P. B., \& Smith, B. (1982). All the women are white, all the blacks are men, but some of us are brave: Black women's studies. New York: The Feminist Press.

Ives, C. (1991). In J. Kirkpatrick (Ed.), Charles E. Ives: Memos. Scranton: W. W. Norton.

James, R. (2012). Loving the alien. The New Inquiry, 9(September). http://thenewinquiry.com/ essays/loving-the-alien/

James, R. (2013). Oppression, privilege, and aesthetics: The use of the aesthetic in theories of race, gender, and sexuality and the role of race, gender, and sexuality in philosophical aesthetics. Philosophy Compass, 8(2), 101-116. https://doi.org/10.1111/phc.3.12002.

James, R. (2014a). Incandescence, melancholy, and feminist bad vibes: A response to Ziarek's Feminist aesthetics and the politics of modernism. Differences, 25(2), 116-129.

James, R. (2014b). Neoliberal noise: Attali, Foucault, and the biopolitics of uncool. Cultural Theory and Critique, 55(2), 138-158. https://doi.org/10.1080/14735784.2014.899881.

James, R. (2015). Resilience and melancholy: Pop music, feminism, neoliberalism. WinchesterlWashington: Zero Books.

Jarman-Ivens, F. (2016, March). Notes on musical camp. In The Ashgate research companion to popular musicology (Chapter 9). https://www.routledgehandbooks.com/doi/10.4324/ 9781315613451.ch9

Koestenbaum, W. (1993). The queen's throat: Opera, homosexuality, and the mystery of desire. New York: Da Capo.

Langenderfer-Magruder, L., Walls, N. E., Kattari, S. K., Whitfield, D. L., \& Ramos, D. (2016). Sexual victimization and subsequent police reporting by gender identity among lesbian, gay, bisexual, transgender, and queer adults. Violence and Victims, 31(2), 320-331.

Ludwig, G. (2016). Desiring neoliberalism. Sexuality Research and Social Policy, 13, 417-427.

Lum, C.-H. (2017). My country, my music: Imagined nostalgia and the crisis of identity in a time of globalization. International Journal of Music Education, 35(1), 47-59.

Mayers, L. (2018). Globalised imaginaries of love and hate: Immutability, violence, and LGBT human rights. Feminist Legal Studies, 26(2), 141-161.

Montgomery, B. (2012, November 11). Recounting the deadly hazing that destroyed FAMU band's reputation. Tampa Bay Times. https://www.tampabay.com/news/humaninterest/recounting-thedeadly-hazing-that-destroyed-famu-bands-reputation/1260765

Powell, A. (2018, March 23). The problems with LGBTQ health care. The Harvard Gazette. https:// news.harvard.edu/gazette/story/2018/03/health-care-providers-need-better-understanding-oflgbtq-patients-harvard-forum-says/

Puar, J. (2007). Terrorist assemblages: Homonationalism in queer times. Durham: Duke University Press. 
Richardson, D. (2005). Desiring sameness? The rise of a neoliberal politics of normalisation. Antipode, 37(3), 515-535.

Taylor, J. (2012a). Playing it queer: Popular music, identity, and queer world-making. Berlin New York: Peter Lang.

Taylor, J. (2012b). Scenes and sexualities: Queerly reframing the music scenes perspective. Continuum: Journal of Media \& Cultural Studies, 26(1), 143-156.

Taylor, J. (2013). Claiming queer territory in the study of popular music. Sociology Compass, 7(3), 194-207.

The NBJC Blog. (2012, September 11). FAMU faults gay drum major Robert Champion, Jr. in his hazing death. National Black Justice Coalition. http://nbjc.org/blog/famu-faults-gay-drummajor-robert-champion-jr-his-hazing-death

Warner, M. (1999). The trouble with normal: Sex, politics, and the ethics of queer life. Cambridge, MA: Harvard University Press.

Wasserbauer, M. (2016). "That's what music is about-It strikes a chord:" Proposing a queer method of listening to the lives and music of LGBTQs. Oral History Review, 43(1), 153-169.

Wilson, N. S. (2009). A queer situation: Poverty, prisons, and performances of infidelity and instability in the New Orleans lesbian anthem. In E. Lewin \& W. L. Leap (Eds.), Out in public: Reinventing lesbian/gay anthropology in a globalizing world (pp. 104-122). Malden: WileyBlackwell.

Winnubst, S. (2012). The queer thing about neoliberal pleasure: A Foucauldian warning. Foucault Studies, 14, 79-97.

Associate Professor Emerita Elizabeth Gould joined the Faculty of Music in 2005, teaching philosophy-based courses in music education and sexual diversity studies. Her research interests include gender and sexuality in the context of the philosophy of Gilles Deleuze and Félix Guattari, feminist assemblages, and queer theory. She is currently investigating interactions of race, class, and gender/sexuality in music education on antebellum Boston's Beacon Hill North Slope.

Open Access This chapter is licensed under the terms of the Creative Commons Attribution 4.0 International License (http://creativecommons.org/licenses/by/4.0/), which permits use, sharing, adaptation, distribution and reproduction in any medium or format, as long as you give appropriate credit to the original author(s) and the source, provide a link to the Creative Commons license and indicate if changes were made.

The images or other third party material in this chapter are included in the chapter's Creative Commons license, unless indicated otherwise in a credit line to the material. If material is not included in the chapter's Creative Commons license and your intended use is not permitted by statutory regulation or exceeds the permitted use, you will need to obtain permission directly from the copyright holder.

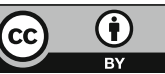

